\title{
STUDY REGARDING THE QUALITY ASSURANCE IN MANUFACTURING PROCESSES
}

\author{
Alina Bianca, $\mathrm{POP}^{1}$ and Mihail Aurel, ȚîȚU ${ }^{2}$ \\ ${ }^{1}$ SC TechnoCAD SA, Baia Mare, România, e-mail: bianca.bontiu@gmail.com \\ ${ }^{2}$ Lucian Blaga University of Sibiu, Sibiu, România, e-mail: mihail.titu@ulbsibiu.ro
}

\begin{abstract}
In this paper, the most important aspects of the quality management of end milling processes on aluminum alloys, are presented. The first part of the paper includes the presentation of the machining activities such: design, planning, programming and control that transform the inputs (workpiece) into finished products. In the second part the research problem was defined by setting a fundamental objective and identifying the specific objectives which contribute to achieve the fundamental objective. In this context an experimental study, was performed, starting with the organization and conducting the end milling process, in which the cutting regime were established, then the characteristic measured parameters were determined, so that the research factors and parameters will result.
\end{abstract}

KEY WORDS: quality management, machining process, aluminum alloy, research problem, research strategy.

\section{INTRODUCTION}

In the literature are several definitions of the quality management.

In the vision of Kelada [1] quality management is a set of activities aimed to achieve some objectives through the resources optimal use. This ensemble includes the planning, coordination, organization, control and quality assurance activities [2].

Juran [3], defines the quality management functions in terms of a "quality trilogy". In his opinion, the quality management comprises three main management processes: quality planning, quality control and quality improvement. In his view, the planning is aimed primarily to develop the products and processes according to the customers' requirements. The quality control means to provide a minimum variation range reported to its relative prescribed level. In this purpose, the values of the measured quality characteristics with the standards specifications are compared, establishing in this way the necessary corrective measures on the entire production flow. In the Juran "trilogy" the quality improvement function is considered the most important. The appropriate processes that this function ensure, are, in Juran's view, the problems elimination that cause the "chronic" quality problems. On the other hand, by improving the quality, the aim is to achieve a higher performance levels required in standards. Therefore, the challenge to be considered, is to provide a higher quality level as against the planned level [2].

Other quality management definitions were given by authors like: Nicolescu [4] Oprean and Țîțu [5].
In this context, in this paper, a quality management methodology of the cutting process will presented, starting with some general aspects as follows.

The cutting process is one of the most common processing techniques in the industry, with a multitude studies on its investigation, from both the industrial, as well as the academic.

In the cutting process, on the workpiece material acts a considerable number of factors, starting with the material microstructure, the cutting tool geometry parameters, the cutting regime, the tool wear, etc.

The workpiece quality and its obtaining costs have a particular importance. In this context, because the machining process is closely related to the costs, it is desired to raise the machine tools and machining centers NC performance, and also the new products continuous development like cutting tools and software development CAD/CAM, which also contributes to increase the machined parts precision.

Also, the industrial market requires of more complex parts manufacture, with precise tolerances, so it is necessary to new machining strategies development concomitant with new cutting tools types in order to facilitate the machining process .

This paper will present the machining activities such: design, planning, programming and control that transform the inputs (workpiece) into finished products. This will be done taking into account the whole range of the technologies and methods used to define how products must be manufactured.

\section{RESEARCH APROACH}

The machining process has a considerable age with a continuous evolution. This evolution is driven by the 
progresses in the new materials developing to produce the pieces, also by the cutting tools and machine tools improvement.

Given that the human development is inseparable from the working tools production, this activity leads to the appearance of a technological environment which was interposed between man and nature. The main problem addressed in this paper is focused on the quality management of the aluminum alloys machining process. In this sense, the approach is based on the Figure 1 scheme, which starts with the raw materials management. In this figure, is covered an entire process starting with the raw material acquisition, than the preparation for the manufacturing process, the heat/chemicals treatments required and the quality inspections performed after each phase.

In the next phase, it is necessary to ensure a high technological piece construction. To accomplish this aspect, the constructive functional solutions are developed to satisfy as well as possible the technical-economic requirements, and the equipment to be achieved with minimal materialized work and also the requirements of social nature to be accomplished.

In general, the manufacturing processes management advantages are [6]:

- the accelerate of the new products introduction;

- the time reducing up to the new products introducing on the market by being able to simultaneously define the product and the manufacturing processes;

- the ability to create and manage the digital plans of the manufacturing processes and of the associated resources;

- the templates processes creation etc.

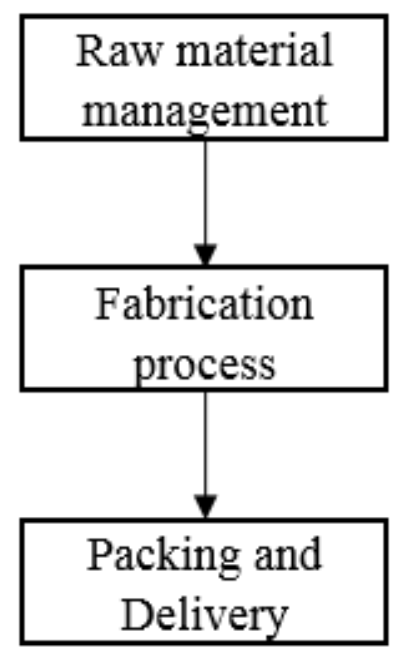

Figure 1. Research problem approach

Regarding this paper, the machining process steps are presented in Figure 2.

\section{INPUT}

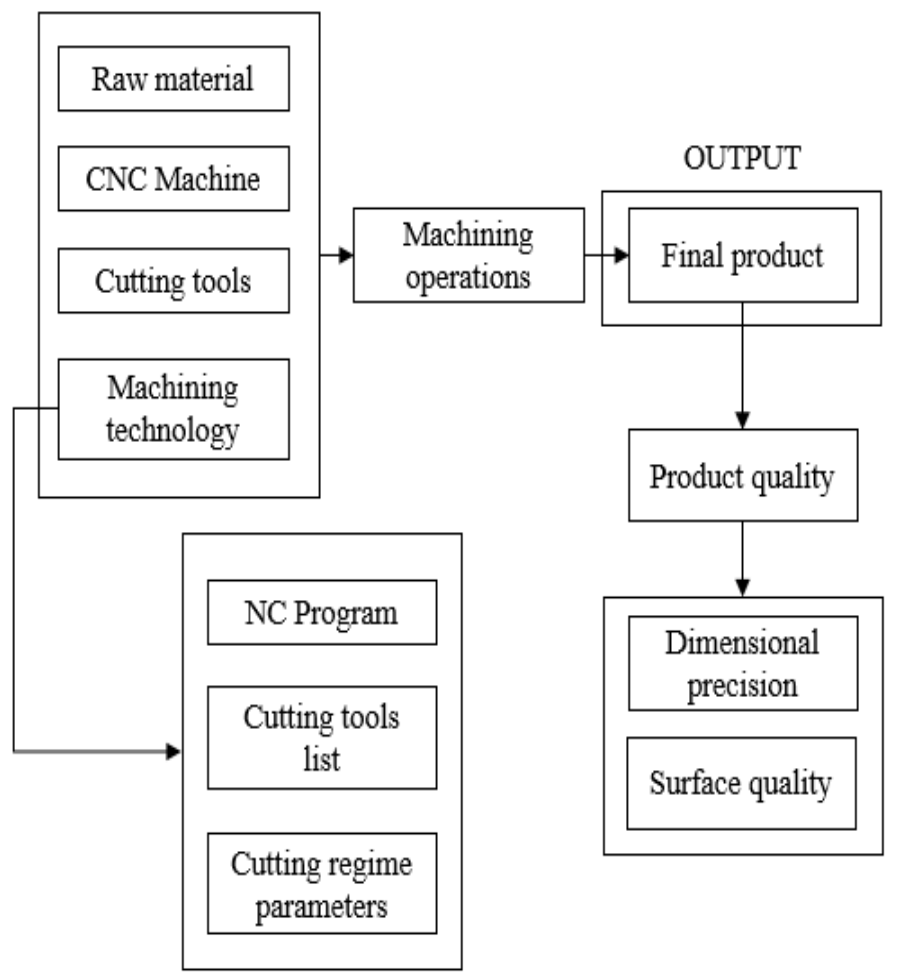

Figure 2. Machining process steps

In this context, a study of aluminum alloys machining process was carried out, as it is show below.

\section{THE STRATEGY OF THE EXPERIMENTAL RESEARCH}

From the experimental point of view, the study has begun with the end milling process planning and carrying out. The cutting regime were established and then, the characteristics parameters were determined and measured, thus resulting the relation between the studied factors and research parameters.

Since the design of experiments is aimed to organizing and planning the experimental work, the researches were focused on:

- in the first phase - to collect the maximum number of information;

- the identification of the factors that affect the analyzed research process;

- the mathematical modeling of experimental data held;

- obtaining the desire regression model established according to the studied factors on the research direction.

\subsection{Research problem definition}

For the beginning the fundamental research objective was defined: the study of the arithmetic mean deviation of the surface profile Ra, resulted from the 7136 aluminum alloys end milling process, depending on the cutting process parameters.

To fulfill this fundamental objective, there must identified the specific objectives which consists in answers to the following research questions [7]:

Question 1: What is the influences percentage of each cutting parameter on the arithmetic mean deviation of the machined surface profile $\mathrm{Ra}$ ? 
Question 2: How is the arithmetic mean deviation of the surface profile $\mathrm{Ra}$, influenced by the each cutting process parameter?

Question 3: It is possible to get a valid mathematical model of $\mathrm{Ra}$, depending on the cutting process parameters?

Question 4: It is possible to make some determined settings on the cutting process parameters in order to obtain a predetermined $\mathrm{Ra}$ ?

The answers of these questions represent the following specific objectives [7]:

Specific objective 1: Calculation of the percentages influences of the cutting process parameters to attain the performance on obtaining an arithmetic mean deviation of the machined surface profile $\mathrm{Ra}$, as good as possible and also, to have a minimum sensitivity of the uncontrollable factors.

Specific objective 2: The Ra experimental determination of the A17136 end milled surface profile, and the data analysis and the interpretation of the measured results.

Specific objective 3: The establishing of the mathematical model to determine the arithmetic mean deviation Ra according to the studied cutting parameters in one established experimentally field.

Specific objective 4: The mathematical model validation and the experimental data optimization.

\subsection{Research design}

After the objectives setting it was conducted the research design, which is based on the issues raised by Figure 3, adapted from [2].

The effective experiments begun with the study of 7136 aluminum alloy behavior according to the proposed objectives under the variation of the cutting regime parameters.

The experiment was performed using a standard set of tools for aluminium machining - $16 \mathrm{~mm}$ End milling cutter milling with $100 \%$ tool engagement - SECO R217.69-1616.0-09-2AN, holding two indexable cutting inserts XOEX090308FR-E05, H15 (fig. 2).

The machine used for the milling tests is a HAAS VF2 CNC. The optical microscope Micro-Vu VERTEX 310 was used to make an optical determination and evaluation of the finished surface.

Also, to analyze the surface roughness for different machining conditions it was used the portable surface roughness tester Mitutoyo SURFTEST SJ-210, with a resolution of $0.002 \mu \mathrm{m}$.

With the experimental stand shown in Figure 4, have been fulfilled the main necessary requirements to achieve the sets objectives and also to obtain the experimental data on which can be analyzed the cutting parameters influence (cutting speed, cutting depth and feed per tooth) exerted on the roughness of the end milled surface.

After the research design, the next step - the establishing of the research strategy, is outlined below.

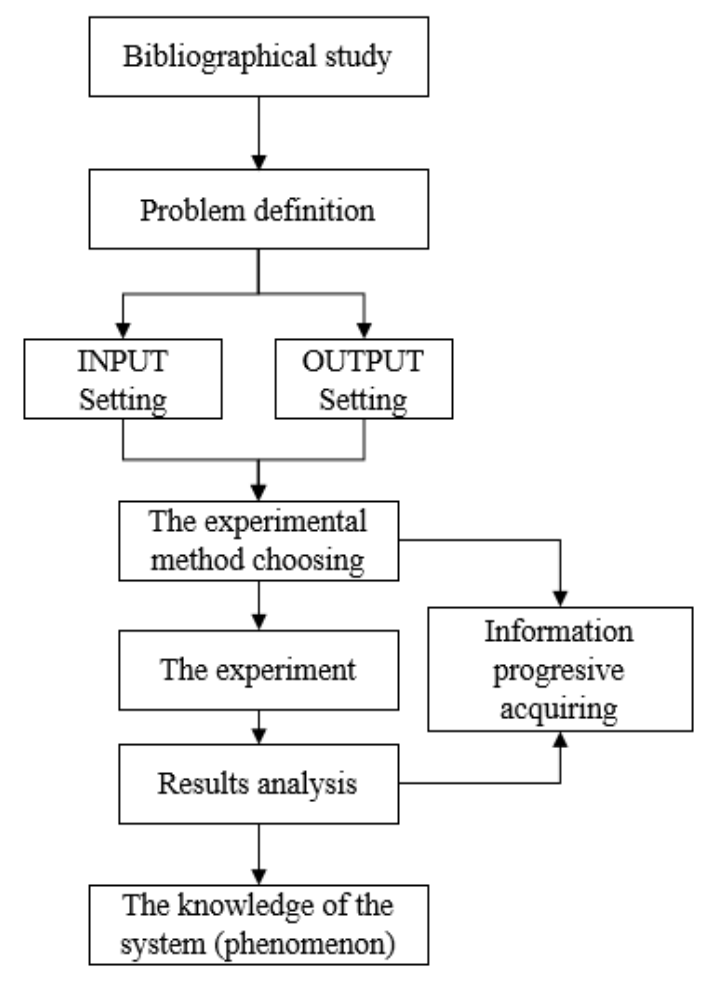

Figure 3. Research design

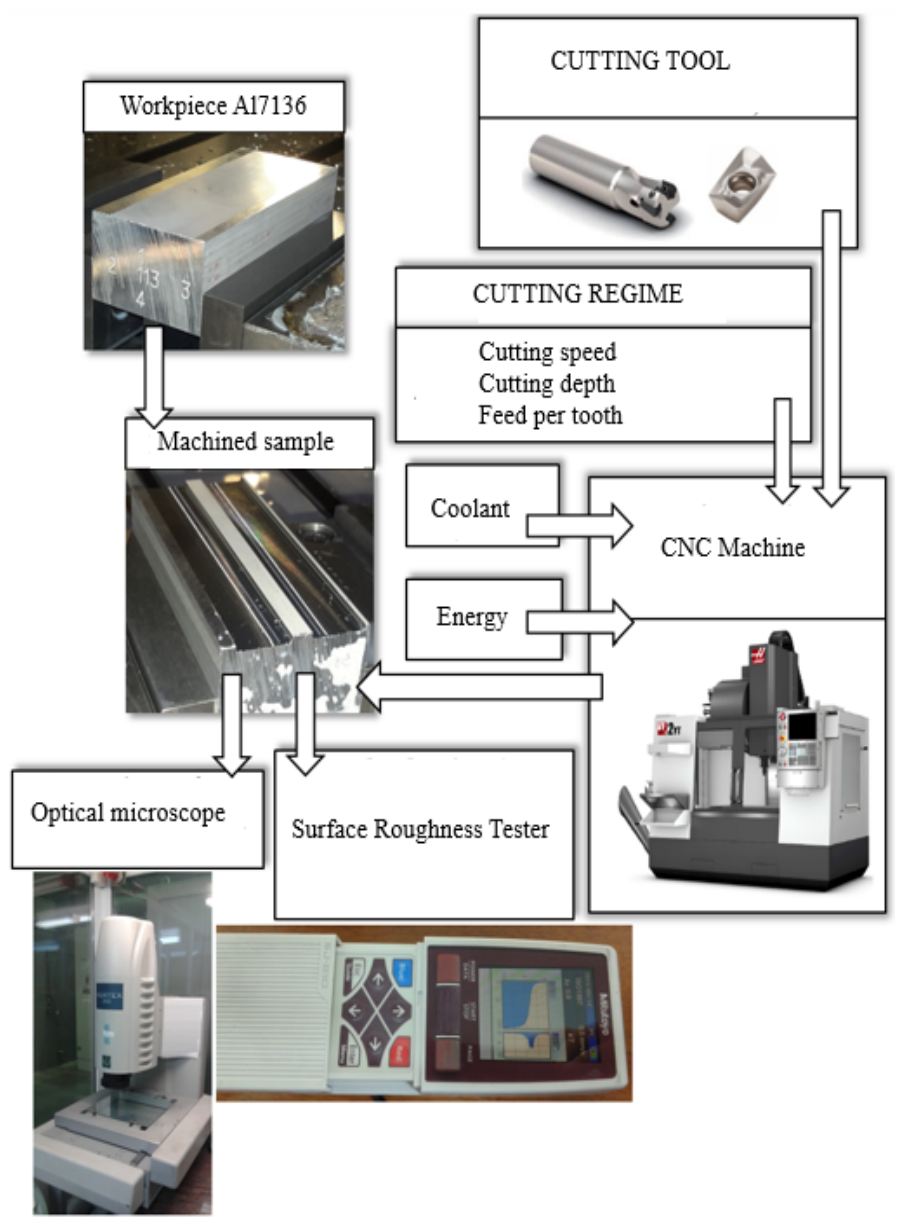

Figure 4. Experimental stand [7] 


\subsection{Research strategy}

As research strategy (Fig. 5), the experimental research study was conducted on the defined problem, starting with an experimental design plan using Taguchi's method.

To make a rational choice of the experimental tests to carry out and also, to obtain the most clear and precise results it is necessary to use modeling and optimization techniques and methods of the experimental research.

Another aspect to mention is that the experimental targets base their knowledge on issues most often addressed on the experimental results obtained by measurement processes.

Now it is accepted that any experimental result is affected by the errors random measurement and thus, the conclusions and decisions must be made under this error, so it is accepted that the statements will have a certainly of lower than $100 \%$ and the probability that the set event occurs based on the analysis of experimental results is sub unitary. [7]

Here comes the statistics, which aims is the decision problem in incertitude.

The decision means the adoption or rejection of a hypothesis. The hypothesis is statistical because it is polls justified.

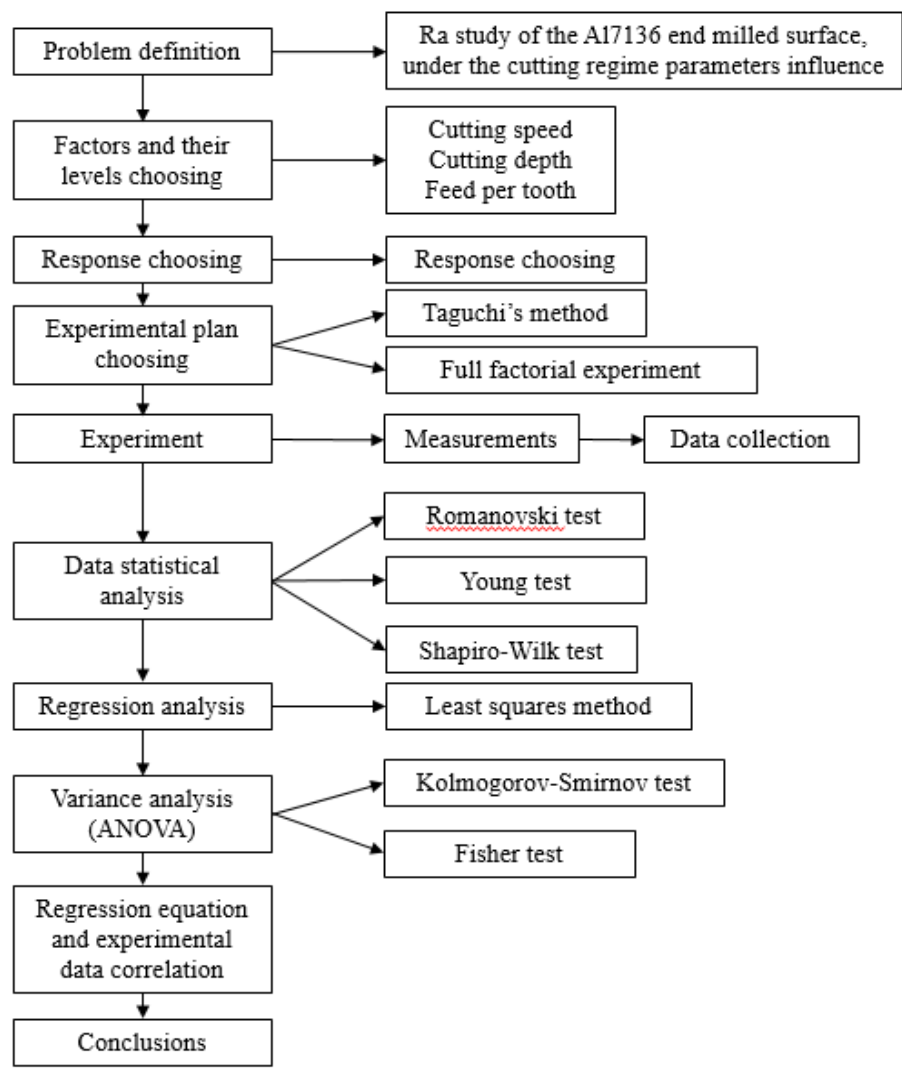

Figure 5. Research strategy [7]

It is referred to the distribution law and to the parameters of a random variable.

The mathematical statistics provides solutions on extracting those interested values of the entire data range for further processing.

Starting with the idea that none of statistical method can prevent mistakes, false reasoning etc., it is necessary and appropriate that the applier of the statistical methods to be familiar with the experimental process and its importance and also to choose the appropriate addressed methods [8].
The experimental data processing was performed using the following steps [8]:

- Statistical hypothesis testing;

- The estimation of the true value of a measurement;

- The elimination of the aberrant results from the series of measurements made on the same conditions;

- Verifying the randomness of the scattering values of the quality characteristic;

- Checking the normality distribution of the experimental data;

- Determination of the range and level of confidence;

- Distribution and reporting of statistics;

- Comparison of averages values;

- Dispersions comparison.

\section{CONCLUSIONS}

The machining process is closely related to the costs, it is desired to raise the machine tools and machining centers $\mathrm{NC}$ performance, and also the new products continuous development like cutting tools and software development $\mathrm{CAD} / \mathrm{CAM}$, which also contributes to increase the machined parts precision.

The machining activities such: design, planning, programming and control that transform the inputs (workpiece) into finished products was done taking into account the whole range of the technologies and methods used to define how products must be manufactured.

With the experimental stand, it have been fulfilled the main necessary requirements to achieve the sets objectives and also to obtain the experimental data on which can be analyzed the cutting parameters influence (cutting speed, cutting depth and feed per tooth) exerted on the roughness of the end milled surface.

The research strategy was established, beginning with a study that was conducted on the defined research problem, with an experimental design plan using Taguchi's method.

For this, it was used modelling and optimizing methods and techniques for the experimental research.

\section{REFERENCES}

1. Kedala, J. Qualite totale et gestion par extraversion, in "Gestiom", 1991.

2. Țîţu, M., Oprean, C. \& Boroiu, A. Cercetarea experimentală aplicată în creşterea calităţii produselor şi serviciilor. Bucureşti Editura AGIR, (2011).

3. Juran, J.M., Gryna, F.M.jr. Calitatea Produselor, Ed. Tehnică, 1973.

4. Nicolescu, O., Plumb, I., Vasilescu, I., Verboncu, I., (coordonatori) Abordări moderne în managementul şi economia organizaţiei, Editura Economică, Bucureşti, 2004:

vol.1 Managementul general al organizaţiei;

vol.2 Managementul pe domenii de activitate;

vol.3 Economia şi managementul diferitelor tipuri de organizaţii;

vol.4 Eficienţa economică şi performanța managementului organizaţiei.

5. Oprean, C., Țîțu, M. Managementul calităţii în economia şi organizaţia bazate pe cunoştinţe, Editura AGIR, Bucureşti, 2008.

6. Shalvi, Marsha, Manufacturing Process Management. A New Era in Manufacturing, (2003). 
7. Bonțiu Pop, Alina Bianca, Calitatea suprafețelor la așchierea aliajelor de aluminiu cu freze cilindro-frontale, Teza de doctorat, Baia Mare, (2015).
8. Năsui, V., Coteţiu, A., Coteţiu, R., Lobonţiu, M. and Ungureanu, N. Bazele cercetării experimentale a actuatorilor electromecanici. Editura Universităţii de Nord, Baia MARE, ISBN 973 - 1729 - 08 - 9, (2007). 